\title{
Combining Inverse and Transport Modeling to Estimate Bacterial Loading and Transport in a Tidal Embayment
}

\author{
Mac Sisson ${ }^{1, *}$, Jian Shen ${ }^{1}$ and Anne Schlegel ${ }^{2}$ \\ 1 Virginia Institute of Marine Science, College of William \& Mary, Gloucester Point, VA 23062, USA; \\ shen@vims.edu \\ 2 Virginia Department of Environmental Quality, Central Office, 629 East Main Street, Richmond, VA 23218, \\ USA; Anne.Schlegel@deq.virginia.gov \\ * Correspondence: sisson@vims.edu; Tel.: +1-804-684-7209 \\ Academic Editor: Rich Signell
}

Received: 2 August 2016; Accepted: 9 October 2016; Published: 2 November 2016

\begin{abstract}
Poquoson River is a tidal coastal embayment located along the Western Shore of the Chesapeake Bay about $4 \mathrm{~km}$ south of the York River mouth in the City of Poquoson and in York County, Virginia. Its drainage area has diversified land uses, including high densities of residence, agricultural, salt marsh land uses, as well as a National Wildlife Refuge. This embayment experiences elevated bacterial concentration due to excess bacterial inputs from storm water runoff, nonpoint sources, and wash off from marshes due to tide and wind-induced set-up and set-down. Bacteria can also grow in the marsh and small tributaries. It is difficult to use a traditional watershed model to simulate bacterial loading, especially in this low-lying marsh area with abundant wildlife, while runoff is not solely driven by precipitation. An inverse approach is introduced to estimate loading from unknown sources based on observations in the embayment. The estimated loadings were combined with loadings estimated from different sources (human, wildlife, agriculture, pets, etc.) and input to the watershed model. The watershed model simulated long-term flow and bacterial loading and discharged to a three-dimensional transport model driven by tide, wind, and freshwater discharge. The transport model efficiently simulates the transport and fate of the bacterial concentration in the embayment and is capable of determining the loading reduction needed to improve the water quality condition of the embayment. Combining inverse, watershed, and transport models is a sound approach for simulating bacterial transport correctly in the coastal embayment with complex unknown bacterial sources, which are not solely driven by precipitation.
\end{abstract}

Keywords: transport modeling; inverse modeling; bacterial loading estimation; traditional watershed modeling

\section{Introduction}

Fecal pathogens of lakes, rivers, and estuaries are hazardous to public health through water contact recreation, and ingestion of contaminated fish and shellfish. Bacterial levels are elevated in many Virginia waters and hundreds of waterbodies are listed as contaminated bacterially. To provide the basis for States to establish water quality-based pollution control, the development of fecal coliform total maximum daily loads (TMDLs) has been mandated to establish the allowable loading for the pollutant that a waterbody can receive without exceeding water quality standards.

Deterministic models have been widely used to simulate bacterial transport. These models are linked to watershed models that provide bacterial loadings discharged to estuaries and lakes [1-4]. For a relatively small coastal embayment, the tidal prism model has often been used for simulating 
bacterial transport and fate $[3,5,6]$. The accuracy of the model simulation depends highly on the correct estimation of daily bacterial loading from the watershed. The watershed models, such as HSPF [7], SWAT [8,9], and LSPC [10], simulate nonpoint source freshwater flow and its associated nonpoint source pollutants. The bacterial loading inputs to the watershed are estimated based on land-use categories and bacterial source distribution including livestock, bio-solids application, wildlife, failing of septic systems, and pets. The advantage of using a watershed model is that it can directly link watershed bacterial sources to the bacterial concentration in the estuaries. It will be extremely useful for understanding the contribution of each bacterial source and to design a management plan to control bacterial loadings. One of the difficulties of using a watershed model is providing bacterial loading to the watershed. These loadings are determined based on the estimation of annual mean results such as wildlife density with consideration of seasonal variation. Because of large variations of watershed land uses and land-use practices, the accurate estimation of bacterial loading is difficult. There are several approaches that have been applied to improve the estimation of bacterial sources based on inverse modeling [11-14]. However, these applications are for estimating an annual mean loading. It is difficult to use them for estimating long-term seasonal and daily loadings. In this study, we propose to use a combined watershed and inverse modeling approach to simulate bacterial loading in the watershed. For those familiar with agricultural bacterial sources, such as bio-solid application and livestock, the watershed model provides a good estimation of sources. For these sources with large variations or unknown sources, such as wildlife and migration birds, the inverse model can be used to estimate seasonal loading and can be used to adjust the bacterial loading for the watershed to improve the watershed model simulations.

The Poquoson River watershed has diversified land uses, including high-density residential, agricultural, and salt marsh land uses, as well as a National Wildlife Refuge. This embayment experiences elevated bacterial concentration due to excess bacterial inputs from stormwater runoff, nonpoint sources, and wash off from marsh areas due to tide and wind-induced set-up and set-down. The bacteria can also grow in the marshes and small tributaries. It is difficult to use a traditional watershed model to simulate bacterial loading, especially in this low-lying marsh area with abundant wildlife, while runoff is not solely driven by precipitation. We combine inverse modeling, watershed modeling (HSPC), and transport modeling (EFDC) to simulate the bacterial transport, which provides a sound approach for simulating bacterial transport correctly in the coastal embayment with complex unknown bacterial sources.

\section{Study Area}

The Poquoson River watershed is located along the Western Shore of the Chesapeake Bay about $4 \mathrm{~km}$ south of the York River mouth (Figure 1). The Poquoson River drains northeast to the main stem of the Bay. The tide range of the embayment is about $0.71 \mathrm{~m}$ and mean water depth is about $2 \mathrm{~m}$. A total of 12 segments of the Poquoson River are listed on the 2006 Virginia 305(b)/303(d) Water Quality Assessment Integrated Report [15] as impaired waterbodies due to violations of the State's water quality standards for fecal coliform and enterococcus.

The Poquoson River watershed has diversified land uses, including high densities of residential, agricultural, and salt marshes, as well as a National Wildlife Refuge. The land-use characterization for the entire Poquoson River watershed was based on land cover 2006 data from the NOAA Coastal Change Analysis Program (C-CAP) (http://www.csc.noaa.gov/digitalcoast/data/ccapregional/). Dominant land uses in the watershed were found to be forest (32\%), wetlands (31\%), and urban and open space (30\%), which account for $93 \%$ of the total area in the watershed. For the adjacent Back Creek, the dominant land uses are wetland (48\%), forest (19\%), and urban $(16 \%)$. A large portion of the watershed is either tidal wetlands or marshes. The surface water runs off from the watershed and discharges to the embayment through stormwater and point sources. The Virginia Division of Health, Department of Shellfish Sanitation (VDH-DSS) is a state agency that has occupied 64 fecal coliform measurement stations (Figure 2) in the Poquoson River during the period 1990-2012. Routine 
measurements are conducted monthly. Figure 3 shows the annual mean fecal coliform concentration from 1990 to 2012. It can be seen that fecal coliform concentrations varied from year to year. High concentrations often occurred in wet hydrological years of 1998, 1999, and 2004, but not always following the precipitation variation. Monthly bacterial distribution is also shown in Figure 3 for the years 1990-2012.

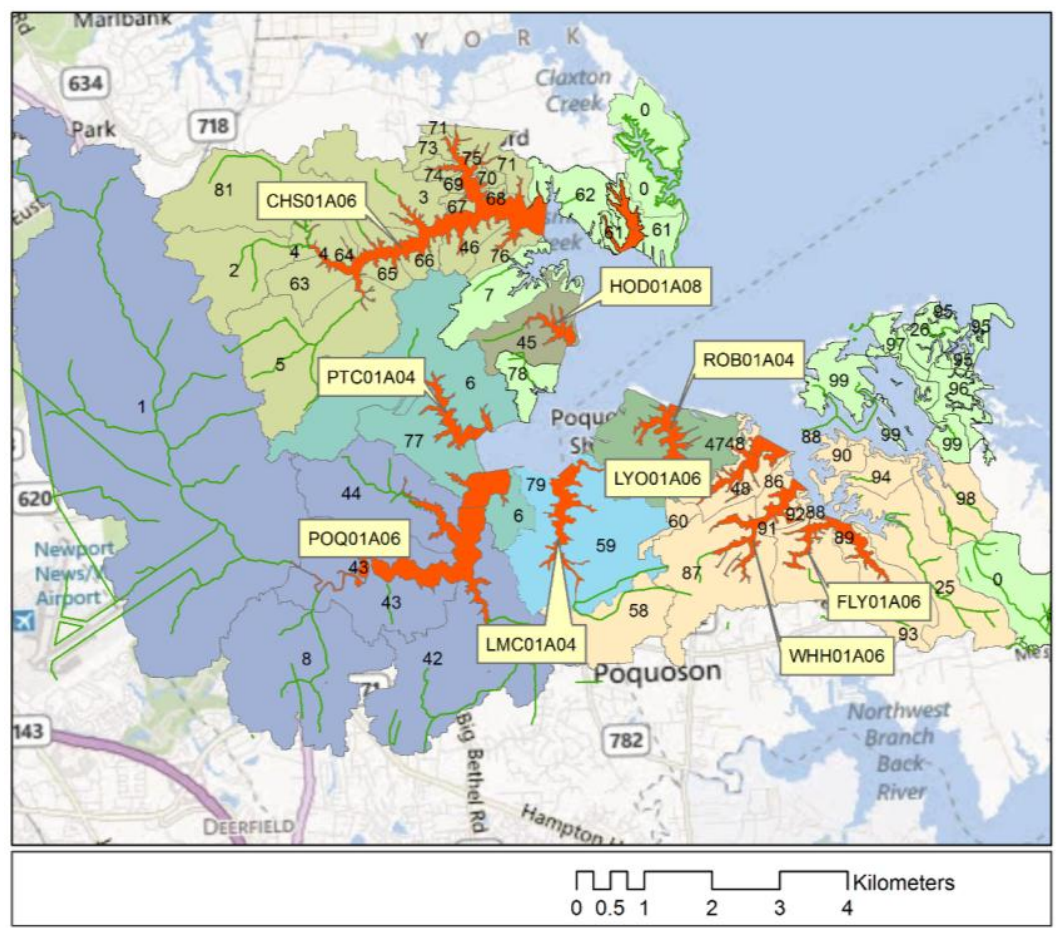

Figure 1. A map of Poquoson River and listed impairment segments (original color).

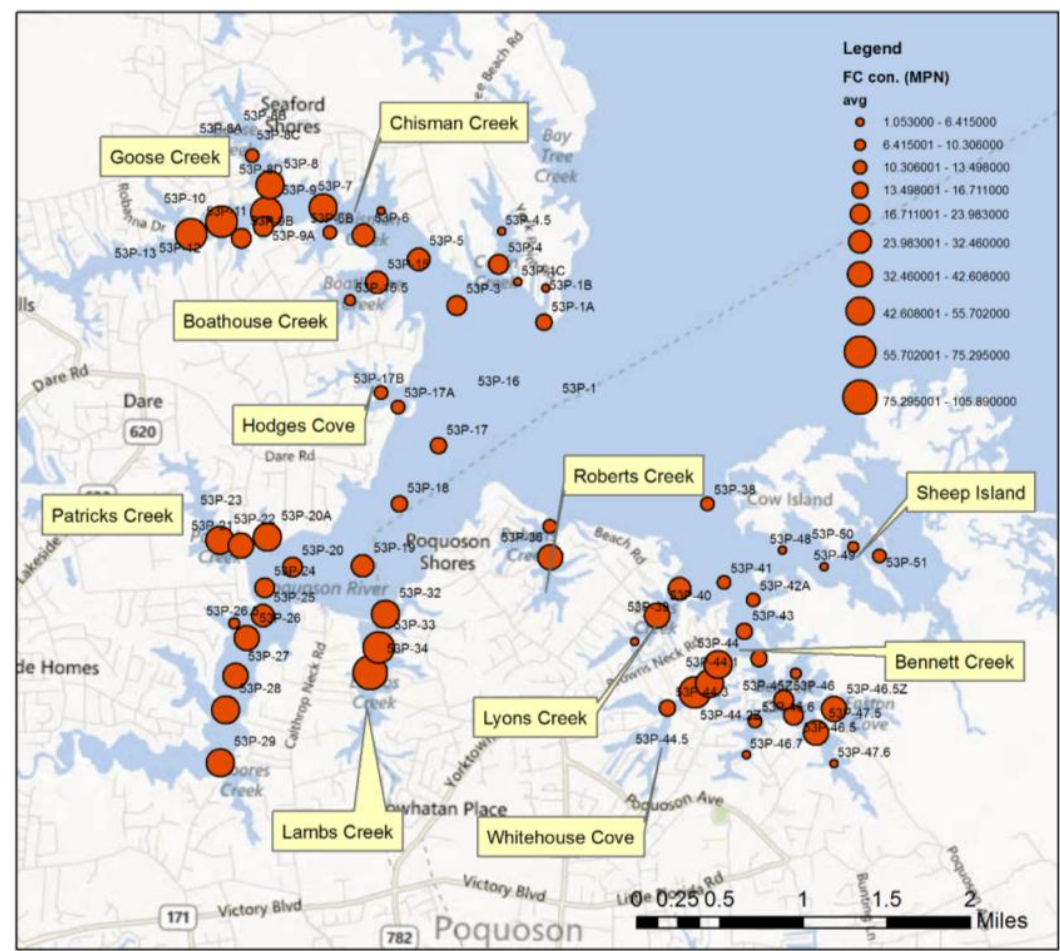

Figure 2. Spatial distribution of mean bacterial concentrations at VDH-DSS stations. 

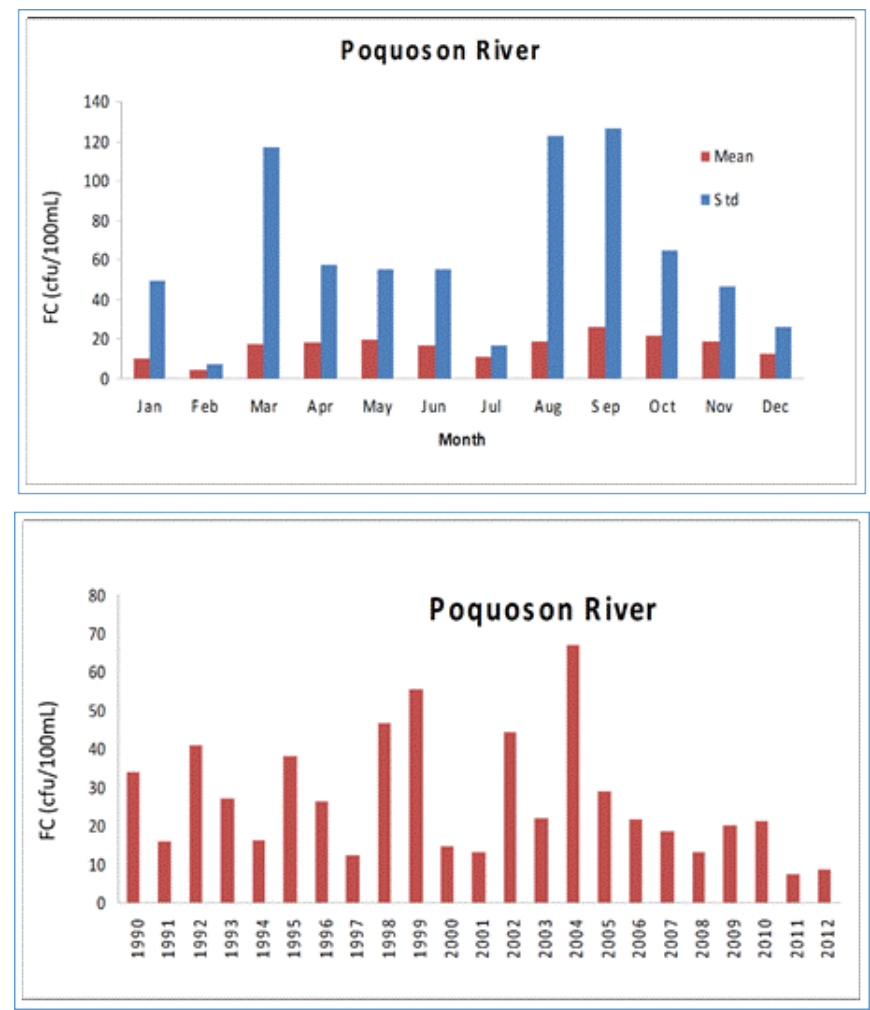

Figure 3. Mean and standard deviation of monthly bacteria distribution (upper panel) and annual mean concentration of fecal bacteria (lower panel) (1990-2012).

Mean daily high concentrations occur in spring (March to May) and fall (August to November). Large variations occur in March, August, and September. The bacteria can also grow in the marsh and small tributaries and be washed off due to tide and wind-induced set-up and set-down. A distribution of average fecal bacterial concentration is shown in Figure 3. It shows that high concentrations are located in the upstream of the tributaries and concentrations decrease gradually toward the downstream due to tidal flushing and decay.

\section{Modeling Approach}

\subsection{Watershed Model}

There are many watershed models that have been used for simulating watershed processes, which include the Hydrologic Simulation Program in FORTRAN (HSPF) [7] and the Soil and Water Assessment Tool (SWART) [8,9]. The watershed model LSPC and hydrodynamics models are used for this study. The LSPC model is a stand-alone, personal computer-based watershed modeling program developed in Microsoft $\mathrm{C}^{++}$[10]. It includes selected HSPF algorithms for simulating hydrology, sediment, and general water quality on land, as well as a simplified stream transport model $[7,10,16,17]$. Like other watershed models, LSPC is a precipitation-driven model and requires necessary meteorological data as model input. The watershed is segmented into 56 hydrologically connected subwatersheds (Figure 1). The land-use input to the model for characterization for the entire Poquoson River watershed was based on land cover 2006 data from the NOAA Coastal Change Analysis Program (C-CAP) (http://www.csc.noaa.gov/digitalcoast/data/ccapregional/). The classification matches part of the National Land Cover Database (NLCD) with more detailed land use for wetlands. The uniqueness of this land use is that it has more detailed land use for wetlands. For modeling purposes, the land uses are grouped by urban pervious and impervious, forest, cropland, wetland, and open space. The pervious and impervious forms of urban land use are obtained from high and median intensity 
residential land uses. The model input to drive the model simulation of runoff is hourly precipitation. The nonpoint source simulation uses a traditional buildup and wash-off approach. Pollutants from various sources (livestock, wildlife, septic systems, bio-solids application, stormwater, etc.) accumulate on the land surface and are subject to runoff during rain events. Different land uses are associated with various anthropogenic and natural processes that determine the potential pollutant load [3]. The human impact is estimated based on failure of septic systems, human population and pets, and point sources. The wildlife population is estimated based on statistical values of the wildlife density for different habitats in this region as shown in Table 1. The pollutants that are contributed by interflow and groundwater are also modeled in LSPC for each land use category. Pollutant loadings from surface runoff, interflow, and groundwater outflow are combined to form the final loading output from LSPC.

Table 1. Typical Wildlife Densities and Wildlife Habitat.

\begin{tabular}{ccc}
\hline Wildlife Type & Population Density & Habitat Requirements \\
\hline Deer & 0.094 animals/acre & Entire watershed, except open water and urban development \\
Raccoon & 0.078 animals/acre & Forest and Wetland within 600 feet of streams and ponds \\
Raccoon & 0.016 animals/acre & Upland Forest \\
Muskrat & $50 /$ mile & Streams and Rivers \\
Nutria & $18.5 / \mathrm{mile}$ & Streams and Rivers \\
Duck/birds & 1.53 animals/acre* & Entire Watershed \\
\hline
\end{tabular}

* 0.77 animals/acre is applied to Plum Tree Island National Wildlife Refuge and $25 \%$ of this density is applied to the rest of the Poquoson River watershed based on tidal prism model.

\subsection{Three-Dimensional Transport Model}

The Environmental Fluid Dynamics Code (EFDC) model is selected to simulate hydrodynamics. EFDC is a general purpose modeling package for simulating 1D, 2D, and 3D flow and transport in surface water systems including: rivers, lakes, estuaries, reservoirs, wetlands, and oceanic coastal regions. It was originally developed at the Virginia Institute of Marine Science for estuarine and coastal applications and is considered public domain software [18,19]. The EFDC model has been integrated into the EPA's TMDL Modeling Toolbox for supporting TMDL development (http:/ /www.epa.gov/ athens/wwqtsc/html/hydrodynamic_models.html). The model grid includes 1593 water cells that cover many tributaries and small embayments (Figure 4). Three layers were used in the vertical for this shallow system, which can simulate stratification in this shallow estuary adequately. The model was forced by hourly tide and salinity at the mouth. The inputs are based on a large Chesapeake Bay model simulation [20]. The surface wind is obtained at Gloucester Point. Temperature is not simulated. A constant decay of 1.0 per day was used for the bacterial loss in the stream [13,21-23]. Numerical model calibration of fecal coliform was conducted for the period of 2008-2012. Daily flow and loading from watershed model simulation is discharged to the 3D model to the grid cells adjacent to the watershed or small creeks of the adjacent watershed. For a watershed that connects to more than one 3D model grid cell, the flow and loading are evenly distributed to the 3D model grids. Because the flow from Harwood Mills Reservoir mainly overflows from the spillway and bacterial concentration inside the reservoir meets the water quality standard, it has a minor influence on the downstream. Therefore, the loading from the watershed of Harwood Mills Reservoir was estimated based on the observation flow and mean bacterial concentration of measurements instead of using output from the watershed model. The 3D model is calibrated for surface elevation and salinity. As there are no NOAA tide observations, the model is calibrated to the predicted tide. A constant roughness height of $0.3 \mathrm{~cm}$ is used for the model. The timestep for the model simulation is $30 \mathrm{~s}$. 


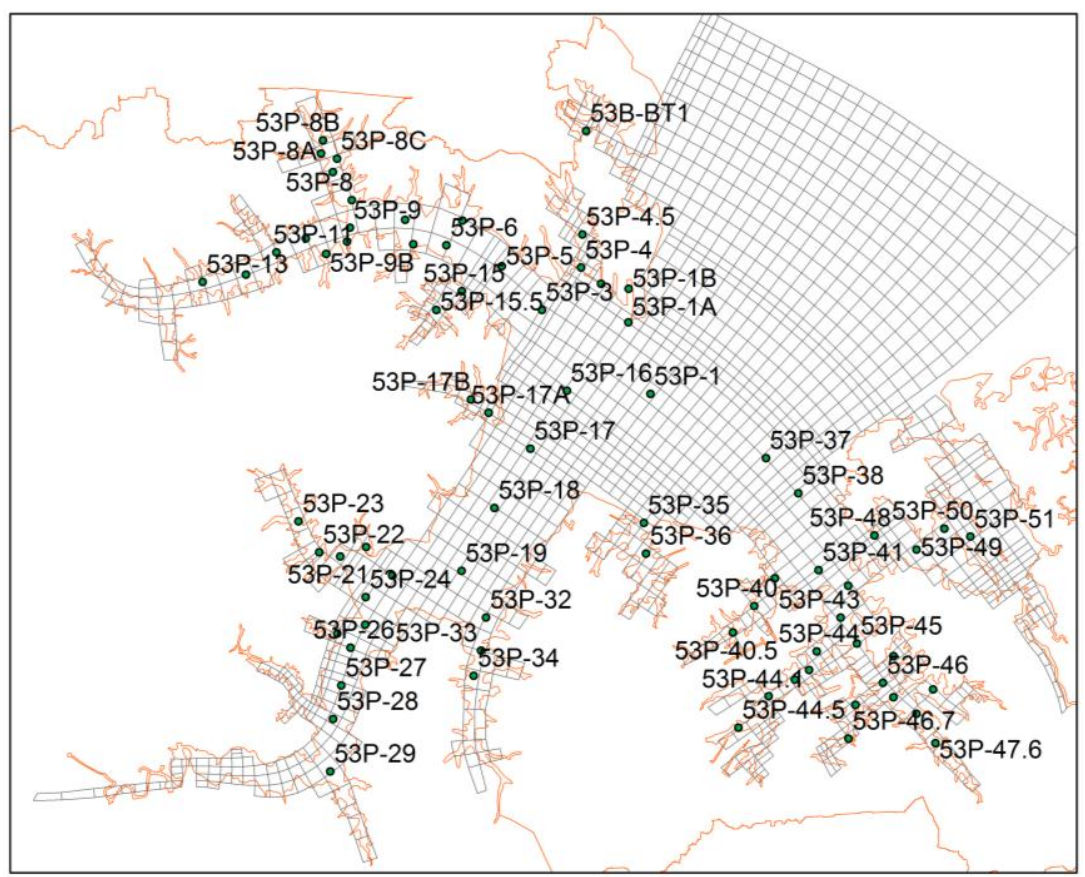

Figure 4. Locations of observation stations and the EFDC numerical model grid.

\subsection{Inverse Tidal Prism Model}

In order to estimate unknown bacterial sources, we used the tidal prism model approach to estimate loading based on observation. Using monthly observations data, the seasonal variation of unknown sources can be estimated. The tidal prism model has been used for the coastal embayment $[5,6]$. In the model, the governing mass-balance equation expressed in the change of mass in a model segment over one tidal cycle, $\Delta m$, is:

$$
\Delta m=[\text { mass in }]-[\text { mass out }]+[\text { sources }]+[\text { kinetics }]
$$

where [mass in] and [mass out] account for the mass transport due to the water movement (referred to as "physical transport processes"), [sources] includes point and nonpoint source inputs over one tidal cycle, and [kinetics] represents the biogeochemical kinetic processes (referred to as "kinetic processes"), which may cause an increase or a decrease of a particular substance within a segment of the water body. Without any loss of generality, three-connection segments including a side tributary segment can be illustrated as shown in Figure 5. The mass balance can be written as:

$$
\begin{gathered}
\frac{d\left(V_{i, j} C_{i, j}\right)}{d t}=Q_{(i+1, j),(i, j)} C_{i+1, j}-Q_{(i, j),(i+1, j)} C_{i, j}+Q_{(i-1, j),(i, j)} C_{i-1, j}-Q_{(i, j),(i-1, j)} C_{i, j}+ \\
Q_{(i, j+1),(i, j)} C_{i, j+1}-Q_{(i, j),(i, j+1)} C_{i, j}-k_{i j} V C_{i, j}+L_{i, j}
\end{gathered}
$$

where $C_{i, j}$ is the bacterial concentration at segment $(i, j), Q_{(i, j),(m, n)}$ is the flux from segment $(i, j)$ to segment $(m, n), V_{i, j}$ is the volume, $R_{i, j}$ is the freshwater upstream of segment of segment $(i, j)$ that includes discharge to segment $(i, j)$, and $k_{i, j}$ is the decay rate. $Q_{(i, j),(m, n)}$ can be computed based on the tidal prism method. For example, the flood flux $Q_{(i, j),(i-1, j)}$ is the tidal prism upstream of the segment $(I-1, j)$, which equals $(1-\alpha) T_{i-1, j}$. Where $T_{i-1, j}$ is the tidal prism upstream of the segment (including) of $(I-1, j)$, that is the volume between high tide and low tide in a tidal cycle. $\alpha$ is the return ratio. Since water brought into the basin on flood tide mixes with the water inside, a portion of the pollutant mass in the basin is flushed out on the following ebb tide. A portion of clean water will flood into the estuary during the next flood tide. The returning ratio ranges from 0 to 1 , and is used to represent 
the fraction of water volume that leaves the basin at falling tide and returns at the following rising tide $[5,6]$. If $\alpha$ exceeds zero, this indicates that a portion equal to $(1-\alpha)$ of the flood water is clean water from downstream. The ebb tide volume $Q_{(i-1, j),(i, j)}=Q_{(i, j),(i-1, j)}+R_{i-1, j}$ is the inflow during the flood phase of tide plus the revised discharge. For Poquoson, the value $\alpha=0.45$ was applied [6].

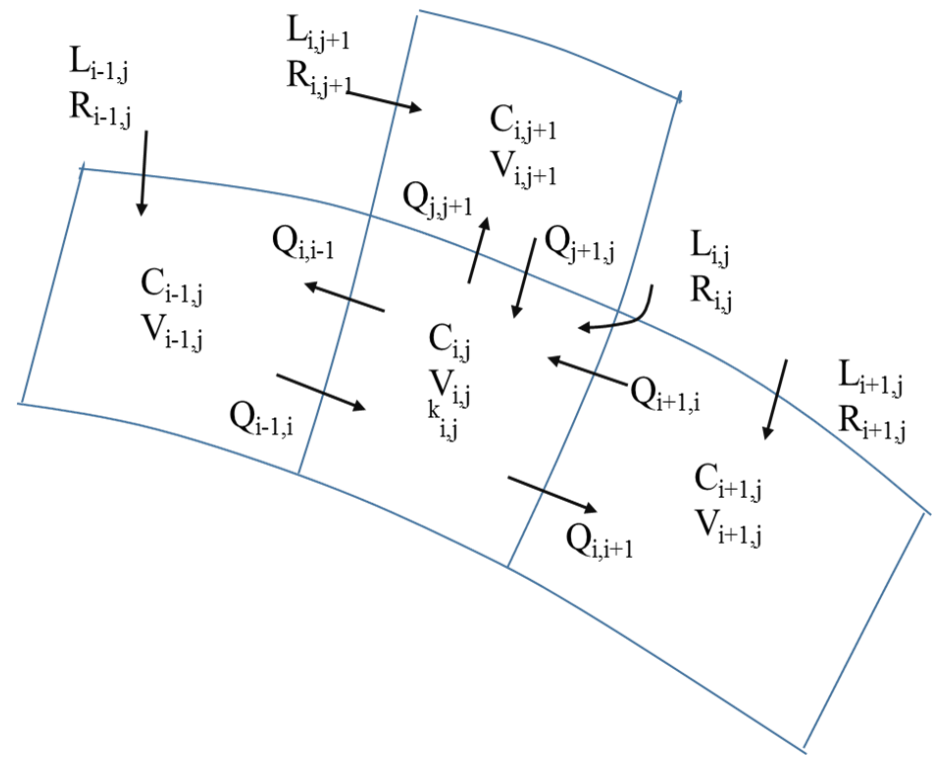

Figure 5. A diagram of tidal model segments.

If we assume that the transport reaches steady state during the measurement period and also assume that all the concentration $C_{i, j}$ and a decay constant are known, the loading $L_{i, j}$ can conveniently be computed from this set of algebraic equations based on Equation (2). The decay rate ranges from 0.7 to 3.0 per day in saltwater [21,22]. A constant decay rate of 1.0/day is used as a conservative approach. The return ratio can be estimated based on the salinity. An average value of 0.4 was applied, which is suitable for Virginia estuaries based on previous study [6]. The segmentation of the tidal prism model is shown in Figure 6. There are 51 segments for the estuary.

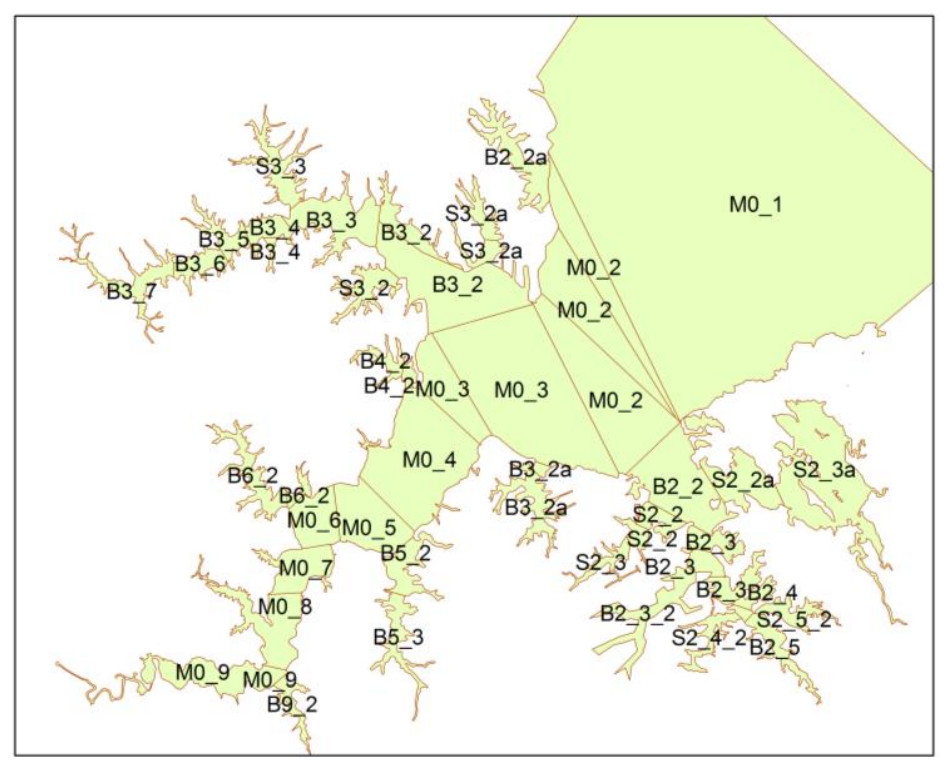

Figure 6. Segmentation and tidal prism model of Poquoson River. 


\section{Model Results and Discussion}

\subsection{Watershed Model}

The hourly precipitation at Gloucester Point is used to drive the model. The calibration process involved adjustment of the model parameters used to represent the hydrologic processes until acceptable agreement between simulated flows and field measurements was achieved. Since there is no USGS gage or any other continuous flow data available in the Poquoson River watershed, a reference watershed was used for calibration. The USGS Gage 01670000 in Beaverdam Swamp near Ark, VA, located approximately 20 miles north of the Poquoson River watershed, is used to calibrate the model parameters for hydrology simulation. This is the only gauge station in this region. The observation period was from 1980 to 1989. The land uses of forest and wetland and soil types are similar to those of the Poquoson River watershed, but it has less urban land. The USGS flow is used mainly for calibration of non-urban land. The US-EPA conducted a watershed simulation for the tidal water region. The EPA model results are also used for the model calibration as the LSPC and the EPA models are similar watershed models. Figure 7 shows the time series comparison of daily stream flow for years 1985 and 1987 for the watershed of Beaverdam Swamp using USGS data and a selected urban subwatershed in the Poquoson River watershed using EPA data. It can be seen that model results match the EPA model results very well as the precipitation data used for this watershed are similar. Based on this comparison, it can be seen that the LSPC model has reasonably reproduced the observations. The key model parameters for the hydrological simulation are listed in Table 2.
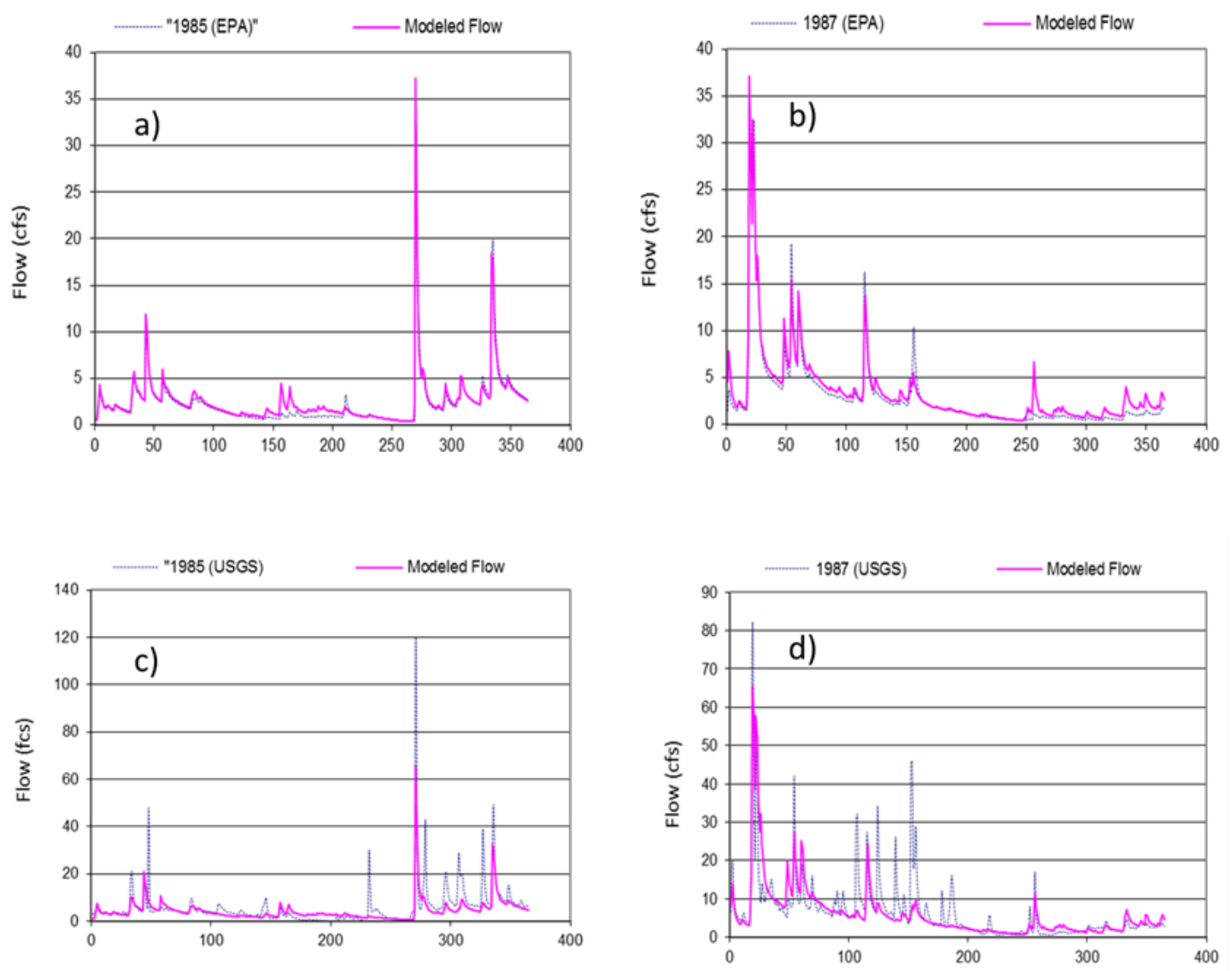

Figure 7. Time Series Comparison of the Daily Stream Flow between Model Simulation and Observed Data from USGS Stream Gage 01670000 in 1985 and 1987 (panels (a,b) show unit acreage flow, panels (c,d) show comparisons to USGS gage). 
Table 2. Key parameters used for hydrological simulation.

\begin{tabular}{ccccc}
\hline Name & Units & Possible Range $^{*}$ & Calibrated Value & Note \\
\hline LZSN & in & $2.0-15$ & 6.93 & lower zone nominal soil moisture storage \\
\hline INFILT & in/h & $0.001-0.50$ & $0.036-0.09$ & index to the infiltration capacity of the soil \\
\hline KVARY & $1 /$ in & $0.85-0.999$ & 1 & variable groundwater recession \\
\hline AGWRC & & $0.0-0.5$ & 0.97 & base groundwater recession \\
\hline BASETP & & $0.0-0.2$ & 0.02 & $\begin{array}{c}\text { fraction of remaining potential e-t that can be } \\
\text { satisfied from base flow }\end{array}$ \\
\hline INFTW & & $1.0-10.0$ & 8 & interflow inflow parameter \\
\hline IRC & $1 /$ day & $0.3-0.85$ & 0.6 & nterflow recession parameter \\
\hline NON-INTERCEPT & in & $0.01-0.40$ & $0.058-0.165$ & interception storage capacity \\
\hline MON-UZSB & in & $0.05-2.0$ & $0.35-0.90$ & upper zone nominal storage \\
\hline MON-LZETP & & $0.1-0.9$ & $0.10-0.60$ & lower zone evapotranspiration parameter \\
\hline
\end{tabular}

\subsection{Tidal Prism Model}

Because a large portion of the watershed is tidal wetlands and marshes, both migratory birds and local residence birds are dominant. The watershed model is set up based on the estimated annual bird population and seasonal variation. However, accurate population and seasonal variations are unknown. The bacteria can also grow in the wetland and marsh areas. To better simulate the loading, the inverse tidal prism model is applied. The estuary was segmented into 51 tidal segments including tributaries. Monthly observation data are averaged for each segment if more than one observation station were found to be located inside the segment. The linear interpolation of bacteria concentration was obtained for the segment without observations. The decay constant used for the tidal prism model is 1.0 per day. Figure 8 shows a comparison of the model simulation of the inverse tidal prism model and the watershed model for four segments in the tidal marsh area. It can be seen that the watershed model under-predicted the loading by one to two orders of magnitude. The average difference of the watershed model prediction of loading and that of the tidal prism model is shown in Figure 9. Large differences often occurred in the marsh and wetland areas. For some urban land uses, the large differences are due to estimations of stormwater. For example, although we can estimate the pet population, it is difficult to estimate the distribution of pet wastes. With the use of loading estimated by the watershed model, we are able to correct the watershed loading input seasonally. We only use a multi-year seasonal average value to correct the watershed loading. Because wildlife is the dominant source, we compute the ratio of the TP model and watershed model and use the ratio to correct the wildlife for forest, wetland, and marsh land-use areas. For urban land use, the correction ratio is also applied to pets. With the use of corrected loading for the watershed, the watershed model was used to simulate the daily flow and bacterial loading. The computed loading for each watershed is fed to the 3D model. 

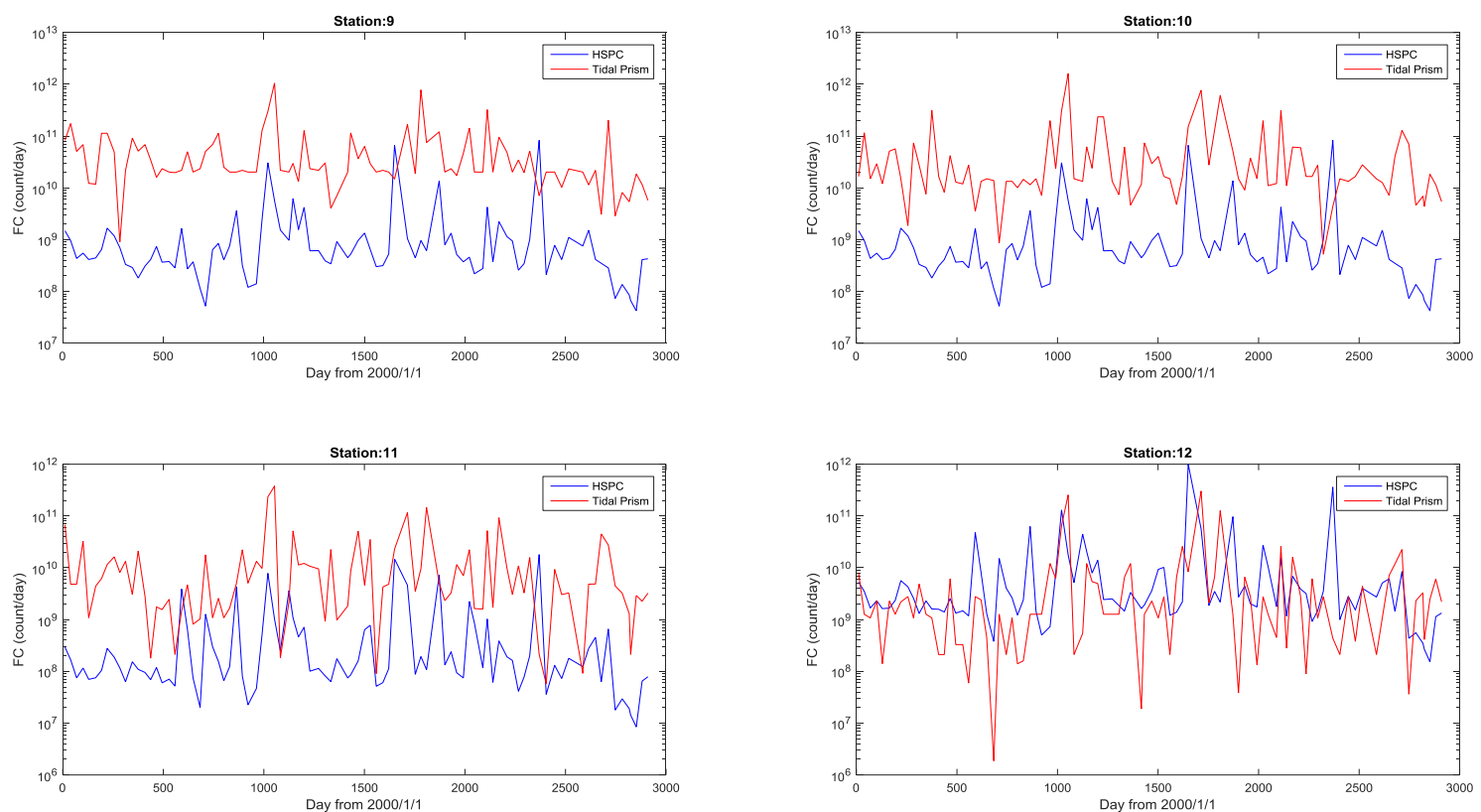

Figure 8. Comparison of bacterial loading simulation between the watershed model and the inverse tidal prism model.

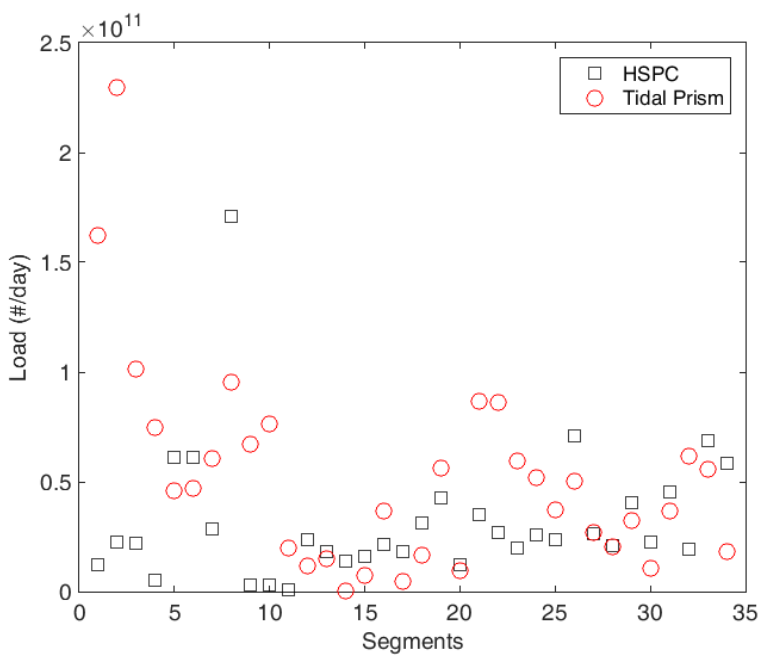

Figure 9. Comparison of model mean loading from 2008 to 2013 between the watershed model (HSPC) and the inverse tidal prism model.

\subsection{Simulation of Bacterial Transport}

The 3D model simulation is conducted from 2008 to 2012. Model results at four selected stations (one in each major region) are shown in Figures 10 and 11, respectively, for the bacterial concentration at stations located at the upstream of Poquoson River, the tributary of Chisman Creek, the tidal marsh area, and the middle of the Poquoson River. It can be seen that the model simulated the observed data quite well. As bacterial concentrations in the River are highly driven by events, i.e., SSOs and boating activities, as well as the direct access of wildlife, some discrepancies can be expected. In particular, the model can miss some observations of high concentration, as the causes of these events are unknown. Overall, model simulations are satisfactory.

It can be seen that the model simulates well for bacterial variation in the estuary. Because many random events are unknown, the model calibration focuses on matching the general seasonal variation 
rather than matching individual events. Another method of comparison of the model results and observations is to view the accumulative fecal coliform concentrations at all observation stations to ensure that the 90th percentile concentration is correctly modeled. Figure 12 shows the comparison of the cumulative distributions of modeled and observed concentrations. It can be seen that the model matches observations very well. These results suggest that there is good agreement between observed data and simulated data during the calibration period, indicating that the model has the ability to simulate bacteria in the Poquoson River and can be applied in the development of the TMDL. Bacteria variations over an eight-year period are consistent.
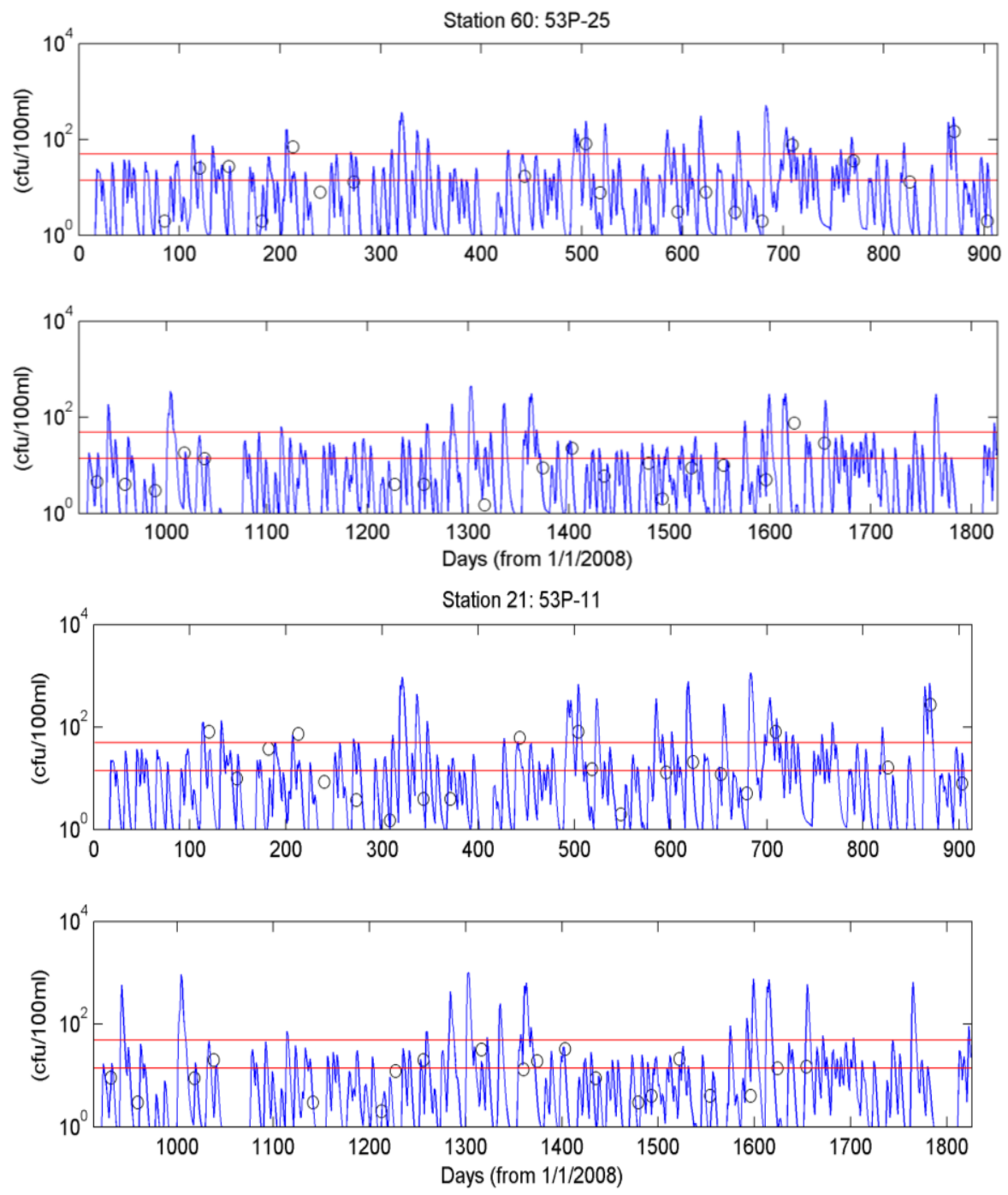

Figure 10. Comparison of model simulation of bacterial concentration and observation for the upstream of Poquoson River and Chisman Creek. 

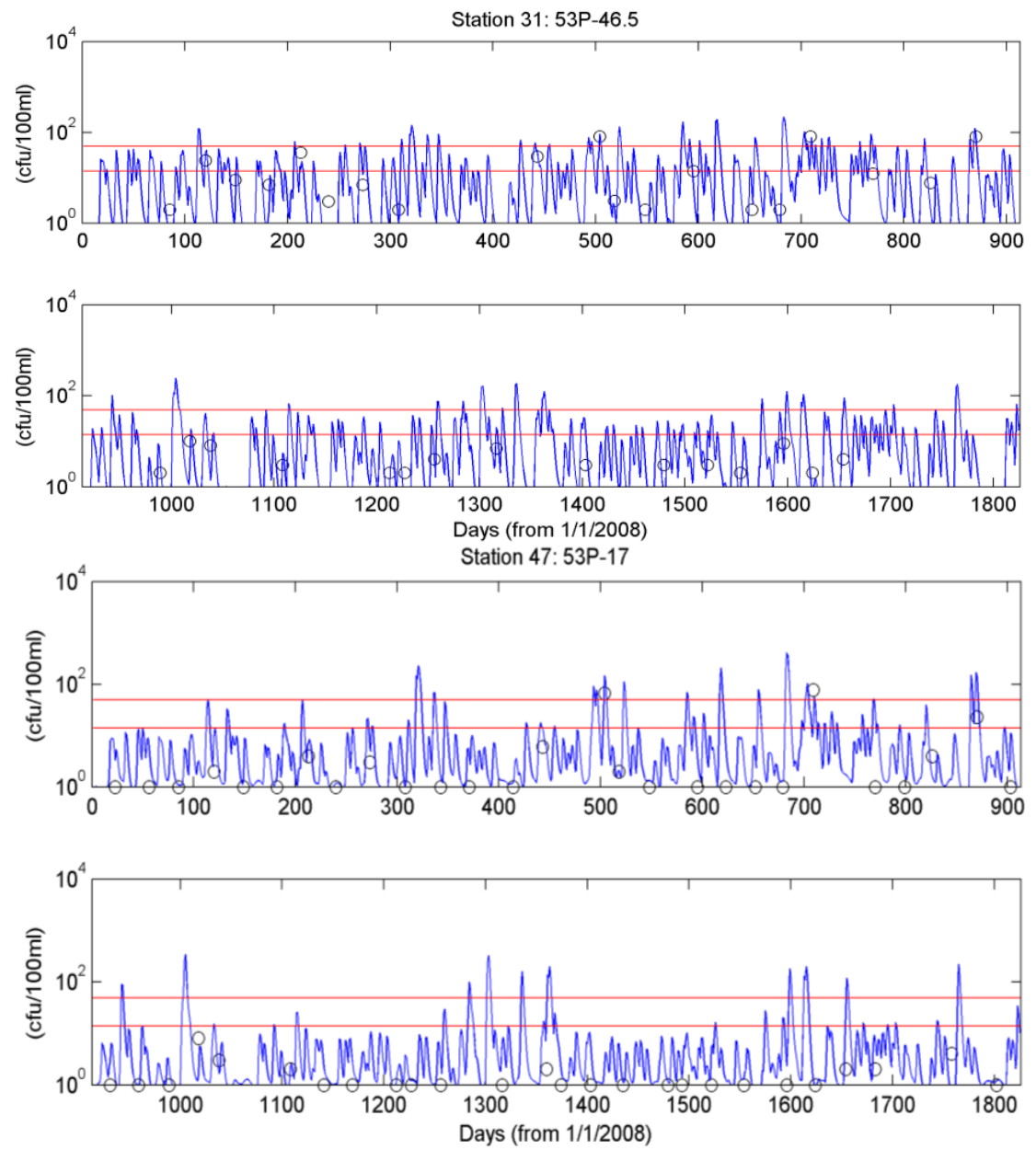

Figure 11. Comparison of model simulation of bacterial concentrations and observations in the tidal marsh area and the middle of the Poquoson River.

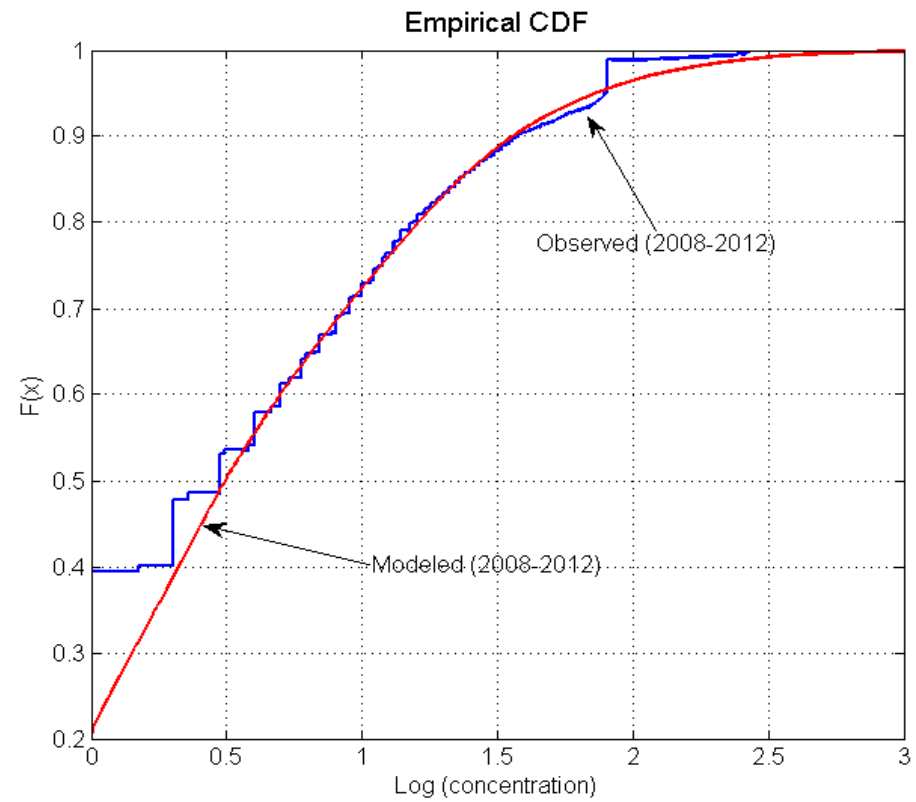

Figure 12. Comparison of cumulative distribution of modeled and observed fecal coliform concentrations at all stations from 2008 to 2012. 


\section{Conclusions}

An approach using a combined watershed model, inverse tidal prism model, and 3D estuary transport model to simulate bacterial concentration in the Poquoson is presented. We introduce the inverse tidal prism model to estimate seasonal bacterial loading. Because the tidal prism model is very efficient in terms of computation, it is feasible to estimate loading, although the spatial resolution is not high enough. The estimated loadings are used to correct the loading input to the watershed model, which is based on the statistical estimation of bacterial loadings for difference bacterial sources, including human, wildlife, agriculture, pets, etc. The watershed model simulates long-term flow and bacterial loading and discharged to a three-dimensional transport model driven by tide, wind, and freshwater discharge. The transport model efficiently simulates the transport and fate of the bacterial concentration in the embayment and is capable of determining the loading reduction needed to improve the water quality condition of the embayment. With the use of inverse modeling, the bacterial loading simulated by the watershed model can be adequately adjusted, which improves both the loading simulation and the 3D model simulation of bacterial transport.

Acknowledgments: The funding of this research project is supported by Virginia Department of Environmental Quality. We thank Daniel Powell of the Department of Health, Division of Shellfish Sanitation (VDH-DSS) and Jennifer Howell of the Department of Environmental Quality, Tidewater Regional Office (DEQ-TRO) for their suggestions.

Author Contributions: Mac Sisson and Jian Shen worked closely on the model development and simulation. Anne Schlegel provided guidance for the TMDL project and approach and reviewed the paper.

Conflicts of Interest: The authors declare no conflict of interest.

\section{References}

1. Im, S.; Brannan, K.M.; Mostaghimi, S.; Cho, J. Simulating fecal coliform bacteria loading from an urbanizing watershed. J. Environ. Sci. Health Part A 2004, 39, 663-679. [CrossRef]

2. Sai, S.; Lung, W.S. Modeling sediment impact on the transport of fecal bacteria. Water Res. 2005, 39, 5232-5240.

3. Shen, J.; Sun, S.; Wang, T. Development of the fecal coliform total maximum daily load using loading simulation program $\mathrm{C}++$ and tidal prism model in estuary shellfish growing areas: A case study in the Nassawadox Coastal Embayment, Virginia. J. Environ. Sci. Health Part A 2005, 40, 1791-1807. [CrossRef]

4. Steets, B.M.; Holden, P.A. A mechanistic model of runoff-associated fecal coliform fate and transport through a coastal lagoon. Water Res. 2003, 37, 589-608. [CrossRef]

5. Kuo, A.Y.; Neilson, B.J. A modified tidal prism model for water quality in small coastal embayments. Water Sci. Technol. 1988, 20, 133-142.

6. Kuo, A.; Park, K.; Kim, S.; Lin, J. A tidal prism water quality model for small coastal basins. Coast. Manag. 2005, 33, 101-117. [CrossRef]

7. Bicknell, B.R.; Imhoff, J.C.; Kittle, J.; Donigian, A.S.; Johansen, R.C. Hydrological Simulation Program—FORTRAN, User's Manual for Release 11; United States Environmental Protection Agency, Environmental Research Laboratory: Athens, GA, USA, 1996.

8. Arnold, J.G.; Moriasi, D.N.; Gassman, P.W.; Abbaspour, K.C.; White, M.J.; Srinvasan, R.; Santhi, C.; Harmel, R.D.; van Griensven, A.; van Liew, M.W.; et al. SWAT: Model use, calibration, and validation. Trans. ASABE 2012, 55, 1491-1508. [CrossRef]

9. Neitsch, S.L.; Arnold, J.G.; Kiniry, J.R.; Williams, J.R. Soil and Water Assessment Tool Theoretical Document; Grassland, Soil and Water Research Laboratory, Agricultural Research Service: Temple, TX, USA, 2005.

10. Shen, J.; Parker, P.; Riverson, J. A new approach for a windows-based watershed modeling system based on a database-supporting architecture. Environ. Model. Softw. 2005, 20, 1127-1138. [CrossRef]

11. Shen, J. Optimal estimation of parameters for an estuarine eutrophication model. Ecol. Model. 2006, 191, 521-537. [CrossRef]

12. Shen, J.; Jia, J.; Sisson, M. Inverse estimation of nonpoint sources of fecal coliform for establishing allowable load for Wye River, Maryland. Water Res. 2006, 40, 3333-3342. [CrossRef] [PubMed]

13. Shen, J.; Zhao, Y. Combined Bayesian statistics and load duration curve method for bacteria nonpoint source loading estimation. Water Res. 2010, 44, 77-84. [CrossRef] [PubMed] 
14. Shen, J.; Zhao, Y. A Bayesian approach for estimating bacterial nonpoint source loading in an estuary with limited observations. J. Environ. Sci. Health Part A 2009, 44, 1574-1584. [CrossRef] [PubMed]

15. VA-DEQ (Virginia Department of Environmental Quality). Total Maximum Daily Load (TMDL) Report for Shellfish Areas Listed due to Bacterial Contamination: Poquoson River and Back Creek; Virginia Institute of Marine Science: Gloucester Point, VA, USA, 2006.

16. USEPA (United States Environmental Protection Agency). Total Maximum Daily Load for Pathogens, Flint Creek Watershed; USEPA: Morgan County, AL, USA, 2001.

17. USEPA (United States Environmental Protection Agency). Total Maximum Daily Load (TMDL) for Metals, Pathogens and Turbidity in the Hurricane Creek Watershed, Tuscaloosa County, Alabama; USEPA: Atlanta, GA, USA, 2001.

18. Hamrick, J.M. A Three-Dimensional Environmental Fluid Dynamics Computer Code: Theoretical and Computational Aspects; Special Report in Applied Marine Science and Ocean Engineering, No. 317; Virginia Institute of Marine Science (VIMS), the College of William and Mary: Gloucester Point, VA, USA, 1992; p. 63.

19. Hamrick, J.M. Estuarine environmental impact assessment using a three-dimensional circulation and transport model. In Proceedings of the 2nd International Conference on Estuarine and Coastal Modeling, Tampa, FL, USA, 13-15 November 1992; ASCE: New York, NY, USA, 1992; pp. 293-303.

20. Hong, B.; Shen, J. Response of estuarine salinity and transport processes to potential future sea-level rise in the Chesapeake Bay. Estuar. Coast. Shelf Sci. 2012, 104, 33-45. [CrossRef]

21. Mancini, J.L. Numerical estimates of coliform mortality rates under various conditions. J. WPCF 1978, 50, $2477-2484$.

22. Thomann, R.V.; Mueller, J.A. Principles of Surface Water Quality Modeling and Control; Harper and Row: New York, NY, USA, 1987.

23. VA-DGIF (Virginia Department of Game and Inland Fisheries). Available online: http://www.dgif.virginia. gov/wp-content/uploads/virginia_deer-management-plan.pdf (accessed on 13 October 2016).

(c) 2016 by the authors; licensee MDPI, Basel, Switzerland. This article is an open access article distributed under the terms and conditions of the Creative Commons Attribution (CC-BY) license (http://creativecommons.org/licenses/by/4.0/). 